\title{
Kinetics of the Oxidation of methyl $n$-propyl ketone by manganese(III) sulphate
}

\author{
K. K. BANERJi, P. NATH, and G. V. Bakore \\ Department of Chemistry, University of Jodhpur, Jodhpur (India) \\ (Z. Naturforsch. 26 b, 30-31 [1971]; received 8 September 1970)
}

\begin{abstract}
The oxidation of methyl $n$-propyl ketone by Mn(III) sulphate in aq. acetic acid is first order with respect to the ketone and Mn(III). The rate is independent of acidity and solvent composition. The activation parameters for oxidation and enolisation were evaluated. Oxidation is faster than enolisation under similar conditions. A mechanism involving an attack on the keto-form by Mn(III) is proposed.
\end{abstract}

Manganese(III) pyrophosphate oxidises cyclohexanone at a rate equal to the rate of enolisation and this supports the belief that ketones are oxidised via their enol form ${ }^{1}$. LITTLER ${ }^{2}$, however, observed that manganese(III) sulphate oxidises cyclohexanone at a rate faster than its enolisation and concluded that the keto-form is directly attacked. Oxidation of aliphatic ketones has not received much attention and hence this investigation was taken up.

\section{Results}

Product Analysis: The completely reduced reaction mixture gives a red-brown colour with ninhydrin in the presence of strong sulphuric acid. This indicates that propionaldehyde is the main oxidation product ${ }^{3}$.

Rate-laws: When the concentration of ketone is in excess, the rate at which $\mathrm{Mn}$ (III) disappears follows first order rate laws. Further the first order rate constant is independent of initial concentration of $\mathrm{Mn}$ (III) (Tab. 1). The oxidation rate varies linearly with the concentration of the ketone (Tab. 2). Variation in the concentration of sulphuric acid, at constant ionic strength, does not appreciably affect the rate oxidation (Tab. 3) .

$10^{3}[\mathrm{Mn}(\mathrm{III})]$

$\left(\mathrm{mol} \cdot l^{-1}\right)$

$10^{4} k_{1}\left(\sec ^{-1}\right)$

$\begin{array}{llllll}2.19 & 3.28 & 4.38 & 6.56 & 8.75 & 10.9\end{array}$

Tab. 1. Oxidant dependence of reaction rate. [Ketone] : $4.61 \times 10^{-2} \mathrm{M}\left[\mathrm{H}_{2} \mathrm{SO}_{4}\right] 4.0 \mathrm{M}[\mathrm{Mn}(\mathrm{II})] 0.22 \mathrm{M}$.

Reprints request to Dr. K. K. BANERJI, Department of Chemistry, University of Jodhpur, Jodhpur (India).

1 A. Y. DRUmmond and W. A. WATERS, J. chem. Soc. [London] 1955, 397.

\begin{tabular}{ccccccc}
\hline $10^{2}[$ Ketone] & & & & & & \\
$\left(\mathrm{mol} \cdot l^{-1}\right)$ & 2.31 & 4.62 & 9.24 & 11.5 & 13.9 & 18.5 \\
$10^{5} k_{1}\left(\mathrm{sec}^{-1}\right)$ & 7.20 & 14.4 & 28.9 & 36.0 & 43.3 & 57.8 \\
$10^{3} \mathrm{k}_{1} /$ & & & & & & \\
{$[$ Ketone] } & 3.12 & 3.12 & 3.13 & 3.13 & 3.11 & 3.12 \\
\hline
\end{tabular}

Tab. 2. Substrate dependence of reaction rate. [Mn (III) ] $4.28 \times 10^{-3} \mathrm{M}\left[\mathrm{H}_{2} \mathrm{SO}_{4}\right] 2.0 \mathrm{M}$ [Mn(II)] $0.21 \mathrm{M}$.

\begin{tabular}{cllllll}
\hline$\left[\mathrm{H}_{2} \mathrm{SO}_{4}\right]$ & & & & & & \\
$\left(\mathrm{mol}^{\prime} l^{-1}\right)$ & 2.0 & 2.5 & 3.0 & 3.5 & 4.0 & 5.0 \\
$10^{4} k_{1}\left(\mathrm{sec}^{-1}\right)$ & 1.44 & 1.60 & 1.44 & 1.20 & 1.44 & 1.20 \\
\hline
\end{tabular}

Tab. 3. Acidity dependence of reaction rate. [Ketone] $4.62 \times 10^{-2} \mathrm{M}$ [Mn(III)] $4.28 \times 10^{-3} \mathrm{M}$ [Mn(II)] $0.11 \mathrm{M}\left[\mathrm{H}_{2} \mathrm{SO}_{4}+\mathrm{NaHSO}_{4}\right] 5.0 \mathrm{M}$.

Addition of $\mathrm{Mn}$ (II) sulphate $(0.05-0.5 \mathrm{M})$ has no effect on the oxidation rate. Similarly changes in proportions of acetic acid $(20-60 \%)$ in the solven: mixture have no effect.

Effect of temperature: Data in Tab. 4 summarize the effect of temperature on the rate of oxidation. The specific rate konstant, $k$ is obtained from the relation, $k=k_{1} /[$ ketone]. A plot of $\log k$ against the inverse of temperature gave a straight line. The Arrhenius equation is, therefore, valid for this reaction.

\begin{tabular}{|c|c|c|c|c|c|}
\hline \\
\hline \multicolumn{6}{|c|}{ Temp. $\left({ }^{\circ} \mathrm{C}\right)_{30}$} \\
\hline \multicolumn{6}{|c|}{$\begin{array}{l}10^{3} k\left(l \cdot \mathrm{mol}^{-1}\right. \\
\left.\sec ^{-1}\right)\end{array}$} \\
\hline & 1.80 & 3.12 & 5.38 & 8.98 & $21.0-4.1$ e.u. \\
\hline
\end{tabular}

Tab. 4. Effect of temperature [Mn(III) ] $4.28 \times 10^{-3} \mathrm{M}$ [Mn(II) ] $0.21 \mathrm{M}\left[\mathrm{H}_{2} \mathrm{SO}_{4}\right] 2.0 \mathrm{M}$.

2 J. S. LitTler, J. chem. Soc. [London] 1962, 832.

3 F. Feigl, "Spot Tests in Organic Analysis", Elsevier, Amsterdam 1966, p. 591. 
Rate of Enolisation: The rates of enolisation were obtained by the bromination method. The bromination of methyl $n$-propyl ketone is first order with respect to the ketone and hydrogen ions but zero order to bromine. The rate of bromination increases with the proportion of acetic acid in the solvent mixture (Tab. 5). The rates of bromination were obtained at different temperatures (Tab. 6).

\begin{tabular}{lcccl}
\hline Acetic acid [\%] & 20 & 30 & 50 & 80 \\
$10^{4} k_{2}\left(l \cdot \mathrm{mol}^{-1} \cdot \mathrm{sec}^{-1}\right)$ & 3.31 & 3.96 & 5.20 & 11.1
\end{tabular}

Tab. 5. Rate of bromination, Temp. $35^{\circ} \mathrm{C}$.

\begin{tabular}{lcccccc}
\hline Solvent & \multicolumn{3}{c}{$5 \%$ acetic acid } & $\Delta H^{*}$ & $\Delta S^{*}$ \\
Temp. $\left[{ }^{\circ} \mathrm{C}\right]$ & 30 & 35 & 40 & $\left(\mathrm{kcal} \cdot \mathrm{mol}^{-1}\right)(\mathrm{e} . \mathrm{u})$. \\
$10^{4} k_{2}\left(l \cdot \mathrm{mol}^{-1} \cdot \mathrm{sec}^{-1}\right)$ & 2.28 & 4.00 & 6.76 & 20.5 & -8.1 \\
& &
\end{tabular}

Tab. 6. Effect of temperature on bromination rate.

\section{Discussion}

Absence of any effect of $\mathrm{Mn}$ (II) on the oxidation rate indicates that $\mathrm{Mn}(\mathrm{III})$ is the only active species. $\mathrm{Mn}$ (II) retards the oxidation effected by $\mathrm{Mn}$ (IV) due to the following equilibrium ${ }^{4,5}$.

$$
\mathrm{Mn}(\mathrm{IV})+\mathrm{Mn} \text { (II) } \rightleftarrows 2 \mathrm{Mn} \text { (III) . }
$$

The kinetics of the oxidation and enolisation of methyl $n$-propyl ketone are quite different. Whereas enolisation is an acid catalysed reaction and is favoured by increase in the proportion of acetic acid in solvent, the oxidation is independent of these variations. The rate of enolisation of methyl

4 T. J. Kemp and W. A. Waters, J. chem. Soc. [London] $1964,339$. $n$-propyl ketone in $20 \%$ acetic acid solution, at $35^{\circ} \mathrm{C}$ is $3.31 \times 10^{-4} l \cdot \mathrm{mol}^{-1} \cdot \mathrm{sec}^{-1}$, while the specific rate constant, $k$, for oxidation under similar condition is $31.2 \times 10^{-4} l \cdot \mathrm{mol}^{-1} \cdot \mathrm{sec}^{-1}$. If enolisation were to precede oxidation, the oxidation rate in the limit could be equal to the rate of enolisation, but could never have exceeded it. This, therefore, clearly shows that oxidation of methyl $n$-propyl ketone by Mn(III) sulphate proceeds by a direct attack on the keto-form.

$\mathrm{CH}_{3} \mathrm{COCH}_{2} \mathrm{CH}_{2} \mathrm{CH}_{3}+\mathrm{Mn}$ (III)

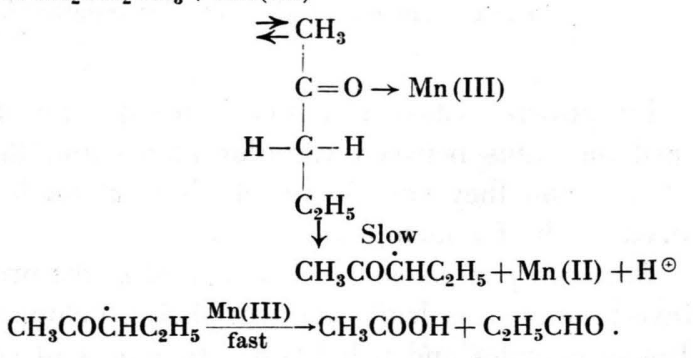

\section{Experimental}

Materials. Methyl $n$-propyl ketore (B.D.H.) was used after fractionation. Acetic acid (99.5\%, B.D.H.) was distilled over chromic acid. All other chemicals used were chemically pure.

Manganese(III) sulphate was prepared as described by VOGEL ${ }^{6}$.

Kinetic measurement. Reactions were carried out at $35{ }^{\circ} \mathrm{C}\left( \pm 0.05^{\circ} \mathrm{C}\right)$ and in $20 \%$ acetic acid solvent unless mentioned otherwise. Concentration of the ketone was always in large excess to that of $\mathrm{Mn}$ (III). A sufficiently large excess of $\mathrm{Mn}$ (II) is added to prevent disproportionation of $\mathrm{Mn}$ (III) to $\mathrm{Mn}(\mathrm{IV})$. The reaction was followed by quenching aliquotes, withdrawn at known intervals of time in slight excess of $\mathrm{Fe}$ (II) and titrating the residual $\mathrm{Fe}$ (II) against $\mathrm{Ce}$ (IV).

5 D. R. Rosseinsky, J. chem. Soc. [London] 1963, 1181.

6 A. I. Vogel, "A Text Book of Quantitative Inorganic Analysis", Longmans Green \& Co., London 1964, p. 327. 